Sharif University of Technology
Scientia Iranica
SCIENTIA
I RAN ICA
http://scientiairanica.sharif.edu

\title{
Strength development of binary cement concrete, using Pulverized Fly Ash (PFA) under various curing conditions
}

\author{
S. Samad ${ }^{\mathrm{a}}$, A. Shah ${ }^{\mathrm{b}, *}$, M.C. Lambachiyac ${ }^{\mathrm{c}}$, and S.B. Desai ${ }^{\mathrm{c}}$ \\ a. Department of Civil Engineering, City University of Science and IT, Peshawar, Pakistan; and Department of Civil Engineering \\ and Construction, Kingston University, London, UK. \\ b. Department of Civil Engineering, City University of Science and IT, Peshawar, Pakistan. \\ c. Faculty of Science, Engineering and Computing at Kingston University, London, UK.
}

Received 22 December 2015; received in revised form 18 June 2016; accepted 14 October 2017

\section{KEYWORDS}

Supplementary

cementitious material;

Pulverized fly ash;

Partial replacement;

Compressive strength;

Curing.

\begin{abstract}
Binary cement incorporating Supplementary Cementitious Material (SCM) is widely used in concrete to reduce the cement consumption in construction industry. Cement production is a major source of emission of Green House Gases (GHG), and there is increasing pressure to reduce its consumption to avoid further global warming, climate changes, etc. In this research, Pulverised fly Ash was used to partially replace cement in the concrete. Three levels of replacement of cement by PFA were selected, and the specimens were cured under summer and winter environments. The strength development characteristics of the blended concrete were compared with the control mix without PFA. The strength gain under winter curing condition was observed as slower. At water cement ratio of 0.35 , concrete with $30 \%$ replacement of cement by PFA achieved high early-age strength. PFA concrete gained more strength than the PC concrete did, after the age of 28 days. The 28-day compressive strength of blended concrete for $30 \%$ of cement replacement by PFA was observed to be nearly the same as that of control concrete mix.

(C) 2019 Sharif University of Technology. All rights reserved.
\end{abstract}

\section{Introduction}

According to the UNEP [1], the concept of sustainability has been known for a long period, and many conferences around the world exist in which governmental and non-governmental organisations have participated to create awareness about the environmental impacts of modern developments. According to the Concrete Centre [2], the amount of Embodied $\mathrm{CO}_{2}\left(\mathrm{ECO}_{2}\right)$ of concrete is a function of the cement content in the

\footnotetext{
*. Corresponding author.

E-mail addresses: hodcivil@cusit.edu.pk (S. Samad), drshah965@gmail.com (A.Shah);

m.limbachiya@kingston.ac.uk (M.C. Lambachiya);

sdesai@blueyonder.co.uk (S.B.Desai)
}

doi: $10.24200 /$ sci. 2017.4537 mix designs. Hence, more production of concrete will lead to more cement consumption and emission of $\mathrm{CO}_{2}$ as a result. To reduce cement contents in concrete, various Supplementary Cementitious Materials (SCM) are used, which include Pulverized Fly Ash (PFA), too.

Brundtland Commission [3] defined sustainable development in 1987 as "the development that meets the needs of the present without compromising the ability of future generations to meet their own needs". The extensive emission of Green House Gases (GHG), due to industrialization and use of fossil fuels in automobiles, has led to global warming, Climate Changes (CC), and other environmental degradations, further intensifying the need for sustainable development [4]. Embodied $\mathrm{CO}_{2}\left(\mathrm{ECO}_{2}\right)$ is the measure of the amount of $\mathrm{CO}_{2}$ emissions generated from the energy needed for the raw material extraction, processing, trans- 
portation, assembling, installation, disassembly, and deconstruction for any system over the duration of a product's life. $\mathrm{ECO}_{2}$ of the construction material is the highest one. For example, $\mathrm{ECO}_{2}$ for cement is $913 \mathrm{~kg} /$ tonne [5]. There is a general understanding that one tonne of cement production leads to almost one tonne of $\mathrm{CO}_{2}$. On the other hand, concrete as construction material has been one of the major inputs of socio-economic development of societies, and its consumption may continue. It is the second largest used material after water and stands at two tonnes per capita per year on global average [6] .

To end poverty, protect the planet, and ensure prosperity for all, as part of a new sustainable development agenda, different countries of the world adopted a set of goals on September 25, 2015. Each goal has specific targets to achieve over the next 15 years. To combat climate change and its impacts is one of the important goals of the Sustainable Development Goals (SDG). The SDG are comprised of 17 goals and 169 targets, which address the social, economic, and environmental dimensions of development. The SDG goal 9 is based on industry, innovation, and infrastructure as well as demanding robust and resilient infrastructure by retrofitting the existing one and construction of new one in the developing and Least Developing Countries (LDC). Hence, the construction industry has to grow, exponentially with the demand for new infrastructure. The cement consumption as a result would also increase greatly, leading to more Green House Gases (GHG) emissions in times to come. To offset the detrimental impacts of cement production, the research on exploring more Supplementary Cementitious Material (SCM) as partial replacement of cement may continue with rigor in future [7]. To offset the negative impacts of the cement production on environment and reduce the cost of concrete, construction industry and concrete technologists around the world have been attempting to explore cementitious and pozzalonic materials. In this context, Ground Granulated Blast Furnace Slag (GGBS) and Pulverized Fly Ash (PFA) have been extensively used during the last two decades. Nailk and Ramme [8,9] used various mix proportions of fly ash added concrete for various levels of substitutions and reported the optimum level up to $55 \%$ to achieve the concrete with 28-day compressive strength in the range of $35 \mathrm{MPa}$. Poon [10] used low calcium High Volume Fly Ash (HVFA) for high strength concrete and achieved 28-day compressive strength of $83 \mathrm{MPa}$. The high Loss on Ignition (LoI) value for fly ash severely affects the compressive strength and creep of concrete when used as replacement of cement in concrete. The un-burnt ash particles increase the water requirement and reduce the compressive strength, too. To reduce this impact, High Range Water Reducers (HRWRs) have been used [11,12]. Huang et al. [13] developed a rational mix design method for concrete having 20$80 \%$ replacement of cement by HVFA. They reported a significant increase in the compressive strength of HVFA blended concretes at later ages such as 90 days and onwards.

According to Higgins [14], UK uses about two million tonnes of GGBS as cement per year, 500,000 tonnes of fly ash as cement addition per year, and 100,000 tonnes of fly ash as a component of blended cement. In China, about 15 million tonnes of GGBS is used per year [15]. According to the information given in the United Kingdom Quality Ash Association (UKQAA) (2004), PFA is a by-product obtained at power stations and is a solid material extracted by electrostatic and mechanical means from flue gases of furnaces fired with pulverised bituminous coal. It is carried by the exhaust gases and recovered as fly ash with fine particles. According to Thomas [16], the use of fly ash as supplementary cementing material in concrete has been known from the start of the last century; however, the first research on fly ash was conducted at the university of California by Davis et al. [17]. The first significant utilization of fly ash in concrete began with the construction of the Hungry Horse Dam in Montana in 1948. The production of the material has changed to reduce the gaseous emissions in recent years, but has not affected the nature of PFA, except that it has increased the Loss On Ignition (LOI). The standards and specification of PFA are covered under BS EN 450-1 (2012) [18] and ACI-committee 226 [19].

PFA has been used widely as cementitious material in construction industry. Dhir [20] found that PFA fineness affected the strength of concrete, and the strength of PFA concrete was reduced by using coarser PFA. In order to take care of the effect of PFA fineness on strength, they developed a simple procedure of varying the water content, cement content, or both. Kayali and Ahmed [21] prepared concrete mixes by replacing $\mathrm{PC}$ with different percentages of fly ash. The water/cement ratio was 0.38 for all the concrete mixes and the total amount of cementitious material content was kept constant for all the mixes and was equal to $450 \mathrm{~kg} / \mathrm{m}^{3}$. The concrete samples were cured with fog for seven days and, then, were air dried until the age of 28 days for testing. They reported that there was a decrease in the compressive strength of concrete made with fly ash, and this decrease was accelerated with the replacement level of fly ash. In the Angel Building, London, self-compacting concrete with $36 \%$ fly ash was used to eliminate the need for conventional methods of compaction, such as vibrating pokers. By using PFA, workability of concrete was improved around difficult interfaces, and the light grey colour of PFA concrete was added to aestheticize the building. According to Neville [22], creep of GGBS 
and PFA concrete is lower than that of the CEM-I concrete, if cured in an environment where there is no moisture loss. Fly ash has been extensively used as a partial replacement to cement in concrete: firstly, to reduce the cement consumption in concrete, thereby making it relatively sustainable material and, secondly, to increase the mechanical properties of concrete in fresh and hardened forms [23]. The environmental considerations of High Volume Fly Ash (HVFA) and its contribution to develop green \& sustainable concrete have been researched extensively [24,25].

\subsection{Effect of curing on strength of fly ash concrete}

The curing process also affects the properties of concrete made from ordinary cement or blended cement incorporating PFA. The water curing was found more effective than heat curing [26,27]. The slow steam curing of PFA added concrete gained strength more than water and air cured specimen [28]. Safan and Kohoutkova [29] reported that continuous water-cured concrete specimens provided a better rate of strength development compared to other curing conditions, and the compressive strength affected by the drying condition varies at different ages. Hongen et al. [30] checked the influence of curing temperature on the compressive strength of Fly Ash based Geo-polymer Concrete (FAGC). The fly ash concrete specimens were cured under different curing conditions. The author concluded that high temperature was vitally important for specimens to gain higher compressive strength, especially the early strength. The specimens cured at room temperature for one day and, then, cured at high temperatures had higher strength than that directly cured at high temperature. Ki-Bong Park and Takafumi Noguchi [31] concluded that the compressive strength of concrete specimens cured in water at $20^{\circ} \mathrm{C}$ was higher than that of the sealed specimen. At low water cement ratio, there is a possibility of selfdesiccation of concrete, and there are limitations to continuous cement hydration, which explains the difference in strength between concrete specimens. External water is required to enable hydration to continue uninhibited. The strength development of concrete made under winter weather conditions $\left(9^{\circ} \mathrm{C}\right)$ was found faster than that of concrete made under summer conditions $\left(20^{\circ} \mathrm{C}\right)$, both for the standard and sealed specimens. For fly ash concrete ( $40 \%$ fly ash), the strength of the specimens made under winter conditions was lower than that made under summer conditions.

In this research, the effects of the partial replacement of cement with PFA on strength development of concrete under different curing conditions have been studied. The use of PFA in concrete tends to slow down the early-age strength, which limits its use in the fast track construction and post-tensioned concrete, subjected to high early loads. Early-age strength of concrete containing PFA can be increased by reducing the water/cement ratio.

\section{Research significance}

There is a limited research work undertaken on effect of compressive strength and strength development characteristics of concrete incorporating PFA in various curing conditions. The non-uniform physical properties of PFA found in various parts of the world also affect the performance of concrete produced. It is expected that the results of the research will add to the existing data on the use of blended cement in concrete and its performance under various curing conditions. The early-age strength of blended concrete is relatively less than that of the normal concrete, restricting its use in many important projects. Based on various trials mixing, the optimal level of water cement ratio, chemical admixtures, and replacement of cement by PFA have been established in various curing conditions. This will contribute to a further number of researches on standardization, properties, and mixing of the concrete made with blended cements.

\section{Experimental program}

\subsection{Material}

3.1.1. Pulverised Fly Ash (PFA)

PFA conforming to BS-EN 450-1 [18] was used as a binary cement component in the production of concrete. PFA used in the concrete is commercially available in the UK and is classified as CEM IV according to BS EN 197-1 (2011) [18].

\subsubsection{Portland cement}

Ordinary Portland Cement (OPC) used conformed to BS EN 197-1 [18] and was classified as CEM-I. The Portland cement was stored in the laboratory to avoid exposure to humidity.

\subsubsection{Superplasticiser (SP)}

High-performance liquid superplasticizers conforming to BS-EN 934-2 [32] were used to achieve the required workability.

\subsubsection{Aggregates}

Graded natural sand with a maximum particle size of $5 \mathrm{~mm}$ and complying with the requirements of $\mathrm{BS}$ EN 12620-1 (2009) [33] was used as fine aggregate in the concrete mixes. Thames valley natural aggregates, averaging $12.5 \mathrm{~mm}$, were used as coarse aggregates in the concrete mixes. The maximum size of the aggregate used was $20 \mathrm{~mm}$.

\subsubsection{Concrete mix proportions}

Trial mixes of concrete were designed to achieve equal 28-day compressive strength of $40 \mathrm{MPa}$ and 
the strength of $10 \mathrm{MPa}$ after 16 hours and $25 \mathrm{MPa}$ after 38 hours to meet the practical requirement of post-tensioned concrete beams. The trial mixes are shown in Tables 1 and 2. To achieve a practical level of workability and cohesion, suitable for pumping, concrete was designed for a target slump of $200 \mathrm{~mm}$. The overall maximum water/cement ratio was maintained at 0.45 and the overall minimum cement content at $340 \mathrm{~kg} / \mathrm{m}^{3}$. A superplasticiser was used to minimise water and cement contents to achieve low free $\mathrm{w} / \mathrm{c}$ ratio.

\subsubsection{Test Samples and testing procedure}

Two batches of concrete were made for each concrete mix to cast samples. Sixty $100 \mathrm{~mm} \times 100 \mathrm{~mm}$ cubes were cast for each mix to measure the compressive strength development according to the British standard test method (BS EN 12390) [34] at the age of 1, 2, 3, $5,7,14,28$, and 56 days cured under different curing regimes.

Two cube specimens from each mix and curing regime were tested for compressive strength using an Avery Denison $2500 \mathrm{kN}$ machine, as shown in Figure 1. In the case of more than $10 \%$ difference in two results, a third specimen was also tested. The concrete samples cured under regime C3 were dried at room temperature for three hours before testing. The specimens were loaded at the rate of $0.4 \mathrm{~N} / \mathrm{s}$ until failure, following the method described in EN 12390-3 (2009) [21].

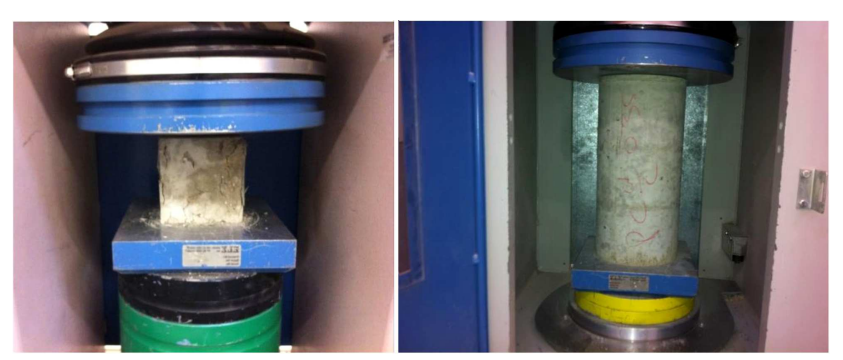

Figure 1. Compressive strength test using Avery Denison $2500 \mathrm{kN}$ machines.

\subsubsection{Curing environments}

Engineering performance of concrete cured under three different regimes was recorded. The following three methods were chosen for curing the concrete, having a close resemblance with the onsite curing environment in the UK.

\subsubsection{Summer Curing Environment (C1)}

After casting concrete in the moulds, it was stored for 24 hours at a laboratory temperature of about $20 \pm 2^{\circ}$ $\mathrm{C}$ and covered with plastic sheets to minimize the loss of moisture. After 24 hours, concrete was demoulded and sealed in air-tight plastic bags so that there is no loss of moisture and stored at a laboratory temperature of $20^{\circ} \mathrm{C}$. This curing environment is titled as $\mathrm{C} 1$ and shown in Figure 2(a).

\subsubsection{Winter curing environment (C2)}

After casting concrete, it was stored for 24 hours in the moulds in the environmental chamber controlled at a temperature of $7^{\circ} \mathrm{C}$ and $55 \%$ relative humidity, which resembles the normal winter temperature in the UK. Moulds were covered with plastic sheets to minimize the loss of moisture. After 24 hours, concrete was demoulded and sealed in the air-tight plastic bags to avoid any loss of moisture and stored in the environmental chamber controlled at $7^{\circ} \mathrm{C}$. Concrete cubes were cured under the $\mathrm{C} 2$ curing environment, as shown in Figure 2(b).

\subsubsection{Water curing environment (C3)}

After casting concrete in the moulds, it was stored at laboratory temperature of $20^{\circ} \mathrm{C}$ and was covered with plastic sheets. After 24 hours, concrete was demoulded and immersed in the water chamber controlled at a temperature of $20 \pm 2^{\circ} \mathrm{C}$. Concrete stored under curing environment $\mathrm{C} 3$ is shown in Figure 2(c).

\section{Results and discussion}

The strength development of various concrete mixes cured under two curing conditions, $\mathrm{C} 1$ and $\mathrm{C} 2$, is shown in Table 2. The compressive strengths of PFA concrete

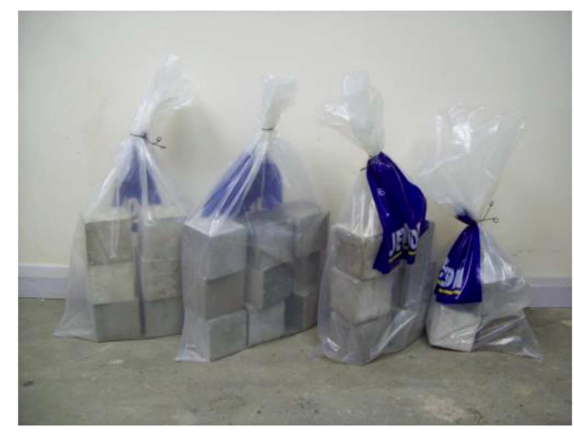

(a) Summer curing condition C1

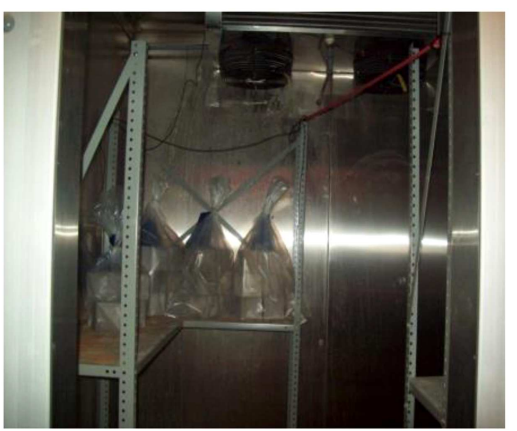

(b) Winter curing environment (C2)

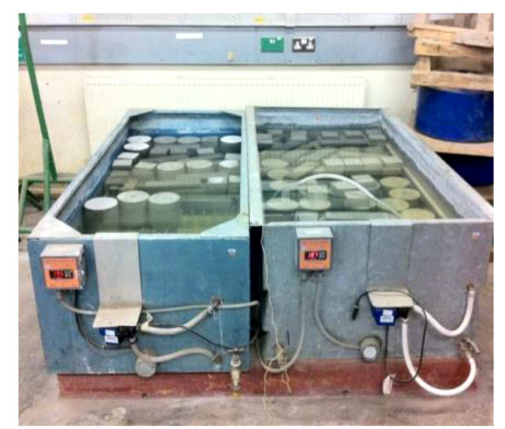

(c) Water curing environment (C3)

Figure 2. Concrete specimens under various curing environments. 
Table 1. Concrete mix proportion.

\begin{tabular}{|c|c|c|c|c|c|c|c|c|c|}
\hline \multirow{3}{*}{$\begin{array}{c}\text { Mix } \\
\text { PC/PFA }\end{array}$} & \multicolumn{7}{|c|}{$\begin{array}{l}\text { Constituent materials } \\
\qquad\left(\mathrm{kg} / \mathrm{m}^{3}\right)\end{array}$} & \multirow{3}{*}{$\begin{array}{c}\text { Calculated } \\
\text { density } \\
\left(\mathrm{kg} / \mathrm{m}^{3}\right)\end{array}$} & \multirow{3}{*}{$\begin{array}{l}\text { Slump } \\
(\mathbf{m m})\end{array}$} \\
\hline & \multirow{2}{*}{$\begin{array}{c}\text { Free } \\
\text { water } \\
\text { (litres) }\end{array}$} & \multicolumn{2}{|c|}{$\begin{array}{c}\text { Binder } \\
\left(\mathrm{kg} / \mathrm{m}^{3}\right)\end{array}$} & \multicolumn{2}{|c|}{$\begin{array}{c}\text { Aggregates } \\
\left(\mathrm{kg} / \mathbf{m}^{\mathbf{3}}\right)\end{array}$} & \multirow[t]{2}{*}{$\begin{array}{l}\mathrm{w} / \mathrm{c} \\
\text { ratio }\end{array}$} & \multirow{2}{*}{$\begin{array}{c}\text { Super plasticiser } \\
(\mathrm{ml} / 100 \mathrm{~kg} \\
\text { of binder })\end{array}$} & & \\
\hline & & PC & PFA & Coarse & Fine & & & & \\
\hline 100PC-control & 160 & 457 & - & 1285 & 500 & 0.35 & 1200 & 2400 & 150 \\
\hline 90PC/10PFA & 150 & 360 & 40 & 1325 & 540 & 0.375 & 1200 & 2415 & 185 \\
\hline $80 \mathrm{PC} / 20 \mathrm{PFA}$ & 150 & 370 & 92 & 1310 & 495 & 0.325 & 1200 & 2415 & 190 \\
\hline $70 \mathrm{PC} / 30 \mathrm{PFA}$ & 150 & 324 & 138 & 1310 & 495 & 0.325 & 1200 & 2415 & 200 \\
\hline
\end{tabular}

Table 2. Compressive strength development of various concrete mixes for summer environment $\mathrm{C} 1$ and winter environment $\mathrm{C} 2$, expressed as \% of compressive strength at 56 days.

\begin{tabular}{|c|c|c|c|c|c|c|c|c|c|}
\hline \multicolumn{10}{|c|}{ Age (days)/compressive strength (MPa) } \\
\hline \multirow[t]{2}{*}{ Curing } & $1 \mathrm{D}^{*}$ & $2 \mathbf{D}$ & $3 \mathbf{D}$ & $5 \mathrm{D}$ & $7 \mathrm{D}$ & $14 \mathrm{D}$ & $28 \mathrm{D}$ & $56 \mathrm{D}$ & $\begin{array}{c}\text { Difference } \\
(\mathrm{MPa} / \%)\end{array}$ \\
\hline & $31 \%$ & $47 \%$ & $56 \%$ & $78 \%$ & $81 \%$ & $88 \%$ & $97 \%$ & $100 \%$ & \\
\hline \multicolumn{10}{|c|}{$100 \mathrm{PC}-$ control-375 kg $/ \mathrm{m}^{3} @ \mathrm{w} / \mathrm{c} 0.40$} \\
\hline \multirow{2}{*}{$\mathrm{C} 1$} & 17 & 25 & 33 & 41.5 & 45.5 & 46.5 & 51.5 & 57.5 & \multirow{5}{*}{$\begin{array}{c}6 \\
(10 \%)\end{array}$} \\
\hline & $30 \%$ & $43 \%$ & $57 \%$ & $72 \%$ & $79 \%$ & $81 \%$ & $90 \%$ & $100 \%$ & \\
\hline \multirow{2}{*}{$\mathrm{C} 2$} & 17 & 24 & 27 & 35 & 36.5 & 39 & 46 & 51.5 & \\
\hline & $33 \%$ & $47 \%$ & $52 \%$ & $68 \%$ & $71 \%$ & $76 \%$ & $89 \%$ & $100 \%$ & \\
\hline C3 & & & & & & & 51.5 & 58 & \\
\hline \multicolumn{10}{|c|}{ 90PC/10PFA@ w/c 0.40} \\
\hline \multirow{2}{*}{$\mathrm{C} 1$} & 13 & 22 & 25.5 & 26.5 & 29 & 31.5 & 41 & 44.5 & \multirow{5}{*}{$\begin{array}{c}4 \\
(9 \%)\end{array}$} \\
\hline & $29 \%$ & $49 \%$ & $57 \%$ & $60 \%$ & $65 \%$ & $71 \%$ & $92 \%$ & $100 \%$ & \\
\hline \multirow{2}{*}{$\mathrm{C} 2$} & 13 & 19.5 & 21 & 23 & 26 & 29 & 31 & 40.5 & \\
\hline & $32 \%$ & $48 \%$ & $52 \%$ & $57 \%$ & $64 \%$ & $72 \%$ & $77 \%$ & $100 \%$ & \\
\hline $\mathrm{C} 3$ & & & & & & & 42.5 & 44 & \\
\hline \multicolumn{10}{|c|}{ 80PC/20PFA@w/c 0.35} \\
\hline \multirow{2}{*}{$\mathrm{C} 1$} & 16.5 & 24.5 & 25.5 & 28 & 30.5 & 38.5 & 42.5 & 46 & \multirow{5}{*}{$\begin{array}{c}4.5 \\
(10 \%)\end{array}$} \\
\hline & $36 \%$ & $53 \%$ & $55 \%$ & $61 \%$ & $66 \%$ & $84 \%$ & $92 \%$ & $100 \%$ & \\
\hline \multirow{2}{*}{$\mathrm{C} 2$} & 16.5 & 19.5 & 21 & 25.5 & 27 & 31.5 & 34 & 41.5 & \\
\hline & $40 \%$ & $47 \%$ & $51 \%$ & $61 \%$ & $65 \%$ & $76 \%$ & $82 \%$ & $100 \%$ & \\
\hline $\mathrm{C} 3$ & & & & & & & 42.5 & 44 & \\
\hline \multicolumn{10}{|c|}{ 70PC/30PFA@ w/c 0.325} \\
\hline \multirow{2}{*}{$\mathrm{C} 1$} & 20 & - & 34 & 38.5 & 41 & 46 & 55 & 65 & \multirow{4}{*}{$\begin{array}{c}7 \\
(10 \%)\end{array}$} \\
\hline & $31 \%$ & & $52 \%$ & $59 \%$ & $63 \%$ & $71 \%$ & $85 \%$ & $100 \%$ & \\
\hline \multirow{2}{*}{$\mathrm{C} 2$} & 20 & - & 28.5 & 30.5 & 34 & 40.5 & 44 & 58 & \\
\hline & $34 \%$ & & $49 \%$ & $53 \%$ & $59 \%$ & $70 \%$ & $76 \%$ & $100 \%$ & \\
\hline
\end{tabular}

*: The representative samples under $\mathrm{C} 1$ and $\mathrm{C} 2$ are de-moulded after one day and tested. Hence, the compressive strengths of the samples are treated the same at the age of 1 day. 
Table 3. Compressive strength at the age of 28 and 56 days cured under various curing regimes.

\begin{tabular}{|c|c|c|c|c|c|c|}
\hline \multirow{3}{*}{ Concrete mix } & \multicolumn{6}{|c|}{ Test age days/comp strength (MPa) } \\
\hline & \multicolumn{3}{|c|}{28 days } & \multicolumn{3}{|c|}{56 days } \\
\hline & C1 & $\mathrm{C2}$ & C3 & C1 & $\mathrm{C2}$ & C3 \\
\hline \multirow{2}{*}{$70 \mathrm{PC} / 30 \mathrm{PFA}$} & 55 & 44 & 56.5 & 65 & 58 & 62 \\
\hline & $97 \%$ & $78 \%$ & $100 \%$ & $105 \%$ & $94 \%$ & $100 \%$ \\
\hline \multirow{2}{*}{$80 \mathrm{PC} / 20 \mathrm{PFA}$} & 42.5 & 34 & 42.5 & 46 & 41.5 & 44 \\
\hline & $100 \%$ & $80 \%$ & $100 \%$ & $104 \%$ & $94 \%$ & $100 \%$ \\
\hline \multirow{2}{*}{$90 \mathrm{PC} / 10 \mathrm{PFA}$} & 41 & 31 & 43 & 44.5 & 40 & 44 \\
\hline & $95 \%$ & $72 \%$ & $100 \%$ & $101 \%$ & $91 \%$ & $100 \%$ \\
\hline \multirow{2}{*}{ 100PC-control } & 51.5 & 46 & 53.5 & 57.5 & 51.5 & 58 \\
\hline & $96 \%$ & $86 \%$ & $100 \%$ & $99 \%$ & $88 \%$ & $100 \%$ \\
\hline
\end{tabular}

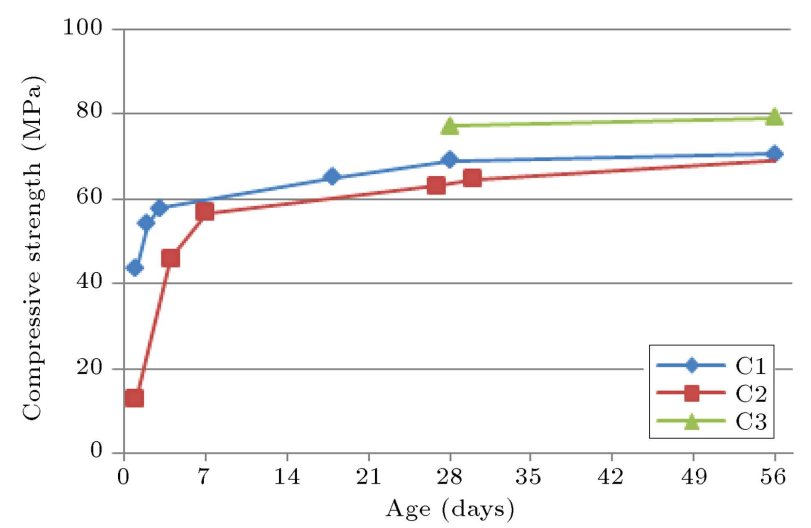

Figure 3. Compressive strength development of 100PC-Control concrete mix under various curing conditions.

under water curing all the curing conditions are given in Table 3. The strength development characteristics of different mixes of concrete under the three regimes are shown in Figures 3, 4, and 5 for control mix, 90PC/10PFA, $80 \mathrm{PC} / 20 \mathrm{PFA}$, and $70 \mathrm{PC} / 30 \mathrm{PFA}$, respectively.

\subsection{Strength development of blended concrete with PFA}

Strength developments of various PFA concrete mixes and $100 \mathrm{PC}$ control mix, cured under curing regime $\mathrm{C} 1$, are compared in Figure 6. The following findings are noted.

- The compressive strength of PFA concrete mixes cured under regime $\mathrm{C} 1$ (cured in sealed plastic bags at $20^{\circ} \mathrm{C}$ ) is slightly less than that cured under regime $\mathrm{C} 3$ (cured under water at $20^{\circ} \mathrm{C}$ ). It is concluded that there is a close correspondence between the compressive strengths of the specimens cured in sealed plastic bags for minimising the loss of moisture and

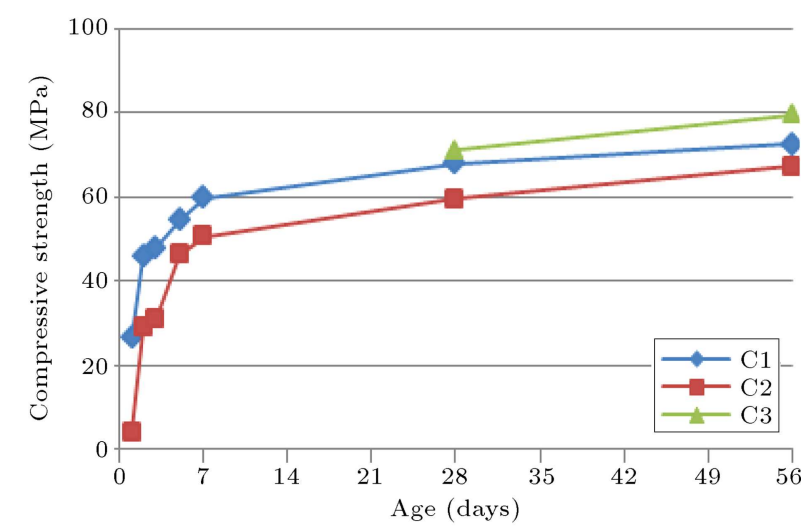

Figure 4. Compressive strength development of 90PC/10PFA concrete mix under various curing conditions.

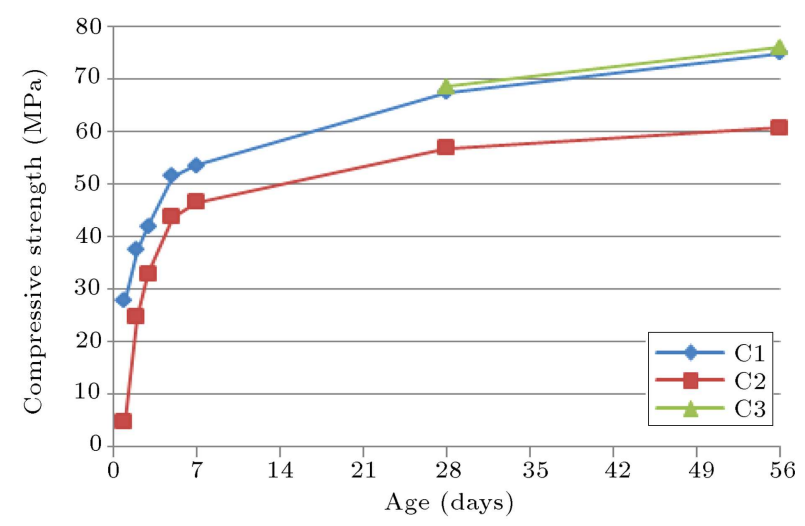

Figure 5. Compressive strength development of 80PC/20PFA concrete mix under various curing conditions.

concrete specimens cured under water at the same temperature of $20^{\circ} \mathrm{C}$;

- The winter curing environment at $7^{\circ} \mathrm{C}(\mathrm{C} 2$ curing environment) affected the strengths of all the con- 
Table 4. Comparison of compressive strengths of blended concrete for various levels of replacement of cement with PFA and control mix with no PFA at the age of 28 and 56 Days.

\begin{tabular}{|c|c|c|c|c|c|c|}
\hline \multirow{3}{*}{ Concrete mix } & \multicolumn{6}{|c|}{ Test age days/comp strength (MPa) } \\
\hline & \multicolumn{3}{|c|}{28 days } & \multicolumn{3}{|c|}{56 days } \\
\hline & C1 & $\mathrm{C2}$ & C3 & C1 & $\mathrm{C2}$ & C3 \\
\hline 100PC-control & 51.5 & 46 & 53.5 & 57.5 & 51.5 & 58 \\
\hline \multirow{2}{*}{$70 \mathrm{PC} / 30 \mathrm{PFA}$} & 55 & 44 & 56.5 & 65 & 58 & 62 \\
\hline & $107 \%$ & $96 \%$ & $106 \%$ & $113 \%$ & $113 \%$ & $107 \%$ \\
\hline \multirow{2}{*}{$80 \mathrm{PC} / 20 \mathrm{PFA}$} & 42.5 & 34 & 42.5 & 46 & 41.5 & 44 \\
\hline & $83 \%$ & $74 \%$ & $79 \%$ & $80 \%$ & $80 \%$ & $76 \%$ \\
\hline \multirow{2}{*}{ 90PC/10 PFA } & 41 & 31 & 43 & 44.5 & 40 & 44 \\
\hline & $80 \%$ & $67 \%$ & $80 \%$ & $77 \%$ & $78 \%$ & $76 \%$ \\
\hline
\end{tabular}

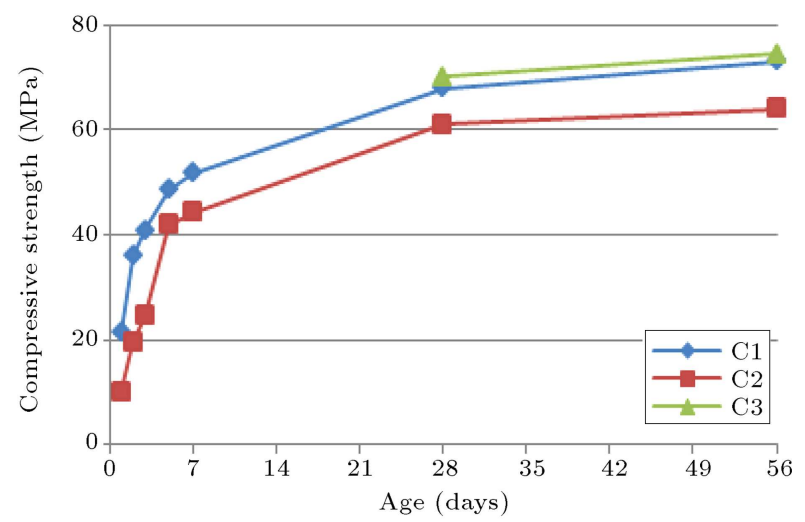

Figure 6. Compressive strength development of 70PC/30PFA concrete mix under various curing conditions.

crete mixes including 100PC-Control concrete mix, but reduced the strength of PFA concrete more than the $100 \mathrm{PC}$-Control concrete mix. In winter, it is recommended that the curing temperature of the PFA concrete be kept at least $20^{\circ} \mathrm{C}$ at early ages to gain enough strength to be used in the fast track construction; to enhance the long-term strength of PFA concrete, an extended curing time is required.

PFA concrete has shown that the early-age strength development is slow due to the apparent slow pozzolanic reactions between $\mathrm{PFA}$ and the lime $\left(\mathrm{Ca}(\mathrm{OH})_{2}\right)$ generated by the $\mathrm{PC}$ concrete. Under curing regime $\mathrm{C} 1$, the strengths of $90 \mathrm{PC} / 10 \mathrm{PFA}$, 80PC/20PFA, and 70PC/30PFA concrete mixes are $25.5 \mathrm{MPa}, 25.5 \mathrm{MPa}$, and $34 \mathrm{MPa}$, respectively, at the 3-day age, as compared to $33 \mathrm{MPa}$ for the $100 \mathrm{PC}$ control concrete mix. At the 14-day age, the strengths increased to $31.5 \mathrm{MPa}, 38.5 \mathrm{MPa}, 46 \mathrm{MPa}$, and $46.5 \mathrm{MPa}$, respectively. At the age of 28 days, these strengths are further increased to $41 \mathrm{MPa}, 42.5 \mathrm{MPa}$,
$55 \mathrm{MPa}$, and 51.5 $\mathrm{MPa}$, respectively. The difference in the compressive strengths at the age of 28 days for $\mathrm{PFA}$ concrete and $100 \mathrm{PC}$ concrete is relatively low. For $70 \mathrm{PC} / 30 \mathrm{PFA}$ at $\mathrm{w} / \mathrm{c}$ ratio of 0.325 , the blended concrete has achieved the maximum of 56-day compressive strength of $65 \mathrm{MPa}$ under curing condition $\mathrm{C} 1$, as compared to $57.5 \mathrm{MPa}$ for $100 \mathrm{PC}$ with no fly ash. The strength gain in PFA concrete is maximum during 28 and 56 days of age. The strength development of PFA-added blended concrete for various cement replacements, under various curing conditions, is also shown as $\%$ of the control mix with no PFA, as shown in Table 4. The comparison in Table 4 shows that $33 \%$ replacement of cement by PFA gives the best results under all curing conditions. The compressive strengths of such concrete are either equal to that of control mix, where no PFA has been used or even greater.

\subsection{Strength development of concrete under various curing conditions}

Strength development of PFA concrete mixes is compared with that of the $\mathrm{PC}$ concrete mix cured under regime $\mathrm{C} 1\left(20^{\circ} \mathrm{C}\right)$ in Figure 7 and cured under regime $\mathrm{C} 2\left(7^{\circ} \mathrm{C}\right)$ in Figure 8.

- The compressive strength for all ages of concrete under winter conditions of curing is low. Hence, low winter temperature $\left(7^{\circ} \mathrm{C}\right)$ has severe impact on compressive strength and the concrete temperature needs to be maintained at minimum summer temperature of 20 . The compressive strength gain under water curing conditions $\mathrm{C} 3$ is, however, the maximum in all cases;

- The 28-day compressive strengths for 70PC/30PFA mix under $\mathrm{C} 1, \mathrm{C} 2$, and $\mathrm{C} 3$ are $55 \mathrm{MPa}, 44 \mathrm{MPa}$, and $56.5 \mathrm{MPa}$, respectively, showing that there is no much difference in strength gain under $\mathrm{C} 1$ and 


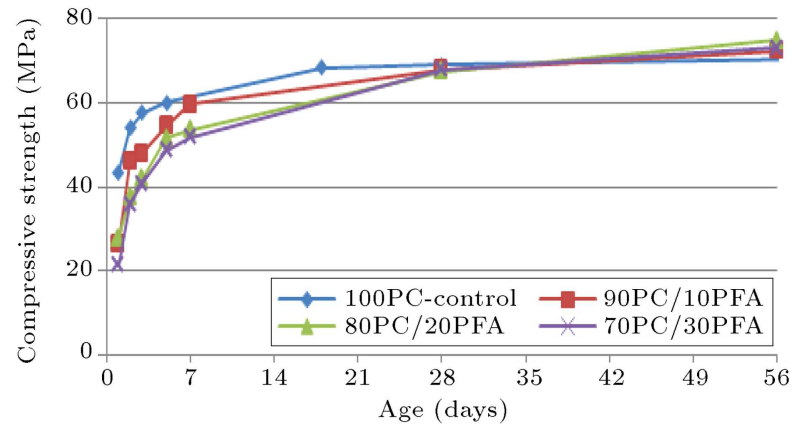

Figure 7. Comparison of compressive strength development of PFA concrete with control mix under C1 curing conditions.

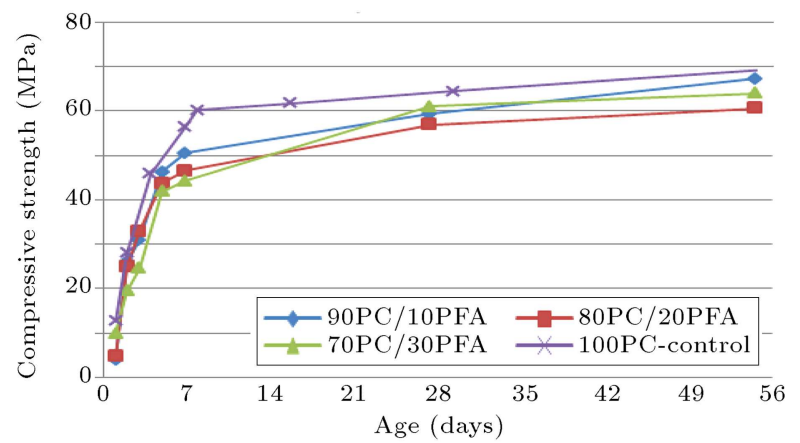

Figure 8. Comparison of compressive strength development of PFA concrete with control mix under $\mathrm{C} 2$ curing conditions.

C3 conditions. For mix $80 \mathrm{PC} / 20 \mathrm{PFA}$, the values are $42.5,34$, and $42.5 \mathrm{MPa}$, respectively. For $\operatorname{mix} 90 \mathrm{PC} / 10 \mathrm{PFA}$, these values are 41, 31, and $43 \mathrm{MPa}$ and for $100 \mathrm{PC}$; the values under three curing conditions are 51.5, 46, and 53.5 MPa, respectively. The comparison of values in Table 2 for 28 days shows that the samples have gained almost the same strength under curing conditions $\mathrm{C} 1$ and $\mathrm{C} 3$ and $72 \%-82 \%$ under $\mathrm{C} 2$ (winter conditions).

The strength gain between the ages of 28 and 56 days is compared in Table 3 and expressed as percentage of 56-day strength of C3 curing conditions when the samples are cured under water. Herein, the strength gain in PFA concrete is relatively faster than the 100PC samples. This is in line with the general observations with the concrete having SCM, where the specified compressive strength is calculated at the age of 56 days, instead of 28 days.

\section{Conclusion and directions for future work}

The following conclusions are made based on the tests blended cement concrete specimen tested under various curing conditions:

- Partial replacement of cement by PFA up to $30 \%$ has little impact on the compressive strength at the age of 28 days when compared with samples having no PFA, as the compressive strength achieved has a reasonable value for use in structural works. This can offer greater opportunity for saving of cement and $\mathrm{CO}_{2}$ emissions, thereby making concrete relatively sustainable;

- The strength development of PFA concrete is relatively slow in the beginning up to 7 days and, then, increases with a relatively high rate. The optimum strength is achieved at 56 days, instead of 28 days of age;

- The results show that there are significant reductions in the rate of strength gain of concrete cured under winter curing conditions $\left(7^{\circ} \mathrm{C}\right)$, as compared to those of summer curing and under water $\left(20^{\circ} \mathrm{C}\right)$. In winter conditions at water cement ratio of 0.35 for concrete containing PFA up to $30 \%$, special care should be taken regarding the temperature increase of the curing environment, especially at the early age to gain enough strength. This can be achieved by covering the concrete in sealed conditions. The heating of concrete buildings, which increases the temperature for curing, is a common practice in cold areas;

- The strength development under the summer conditions and under water is almost the same for PFA concrete in which cement is partially replaced by $20 \%$ and $30 \%$;

- Based on the comparison of the compressive strength developments of PFA concrete results between the ages of 28 and 56 days, it is evident that the strength gain is relatively higher during this period as compared to the $100 \% \mathrm{PC}$ concrete with no PFA. It is more advisable to use the specified strength of PFA concrete at the age of 56 days, as already suggested by earlier research on the blended concrete.

For future works, the following are recommended.

- To check the effects of extreme summer temperature on strength development of PFA concrete;

- To check the impact of curing temperature on normal strength concrete containing PFA;

- To estimate the environmental benefits associated with using PFA in concrete as a partial replacement of cement.

\section{Acknowledgement}

We would like to pay special thanks to the Kingston University, UK, and the technical staff of Concrete and Materials Laboratory, especially Mr. Peter and Mr. Howard who assisted us during the experimental work. 


\section{References}

1. UN (1983) "Report of the world commission on environment and development", [online] available at: http://www.un.org/documents/ga/res/42/ares42187.htm (Accessed 4 May, 2010).

2. The Concrete Centre "Concrete industry sustainability performance report", Surrey, UK, [online] available at http://www.sustainableconcrete.org.uk/ (Accessed 15 Feb, 2011) (2010).

3. Brundtland Commission "Our common future", Technical Report, World Commission on Environment and Development (WCED), Oxford University Press (1987).

4. Struble, L. and Godfrey, J. "How sustainable is concrete?", Proceedings of the International Workshop on Sustainable Development and Concrete Technology, Beijing, China, pp. 201-211 (2004).

5. United Kingdom Quality Ash Association "Embodied $\mathrm{CO}_{2}$ of UK cement, additions and cementitious material", Technical Data Sheet 8.3, MPA UK quality Ash association; [online] available at http://www.ukqaa.org.uk. (Accessed 4th October, 2012) (2010).

6. Harrison, A.J.W., TecEco Cement Concretes - Abatement, Sequestration and Waste Utilization in the Built Environment, TecEco Pty. Ltd, Hobart, Tasmania, Australia, [online] (Accessed 12th March, 2012). Available at: http://www.tececo.com/files/ conference\% 20papers/TecEco TechnologyA batementSequest rationandWasteUtilsation290105.pdf (2003).

7. http://www.un.org/sustainabledevelopment/ sustainable-development-goals/ (Accessed 14th June, 2017).

8. Naik, T.R. and Ramme, B.W. "Setting and hardening of high fly ash content concrete", American Coal Ash Association's 8th International Coal Ash Utilization Symposium, Washington, American Coal Ash Association, pp. 16-120 (1987).

9. Naik, T.R. and Ramme, B.W. "High strength concrete containing large quantities of fly ash", ACI Mater J., 86(2), pp. 111-7 (1989).

10. Poon, C.S. "Study on high strength concrete prepared with large volumes of low calcium fly ash", Cem. Concr. Res., 30(3), pp. 447-55 (2000).

11. Berry, E.E. and Malhorta, V.M. "Fly ash for use in concrete - a critical review", ACI Mater. J., 77(2), pp. 59-73 (1980).

12. Lee, T. and Wu, L.S. "Effects of the LOI of fly ash on the concrete properties", Conference on the Application of Fly-Ash Concrete in Taiwan, Department of Civil Engineering of National Central University, pp. 17-23 (1992).

13. Huang, C.H., Lin, S.K., and Chen, H.J. "Mix proportions and mechanical properties of concrete containing very high-volume of class F fly ash" Construction and Building Materials, 46, pp. 71-78 (2013).
14. Higgins, D. "Sustainable concrete: How can additions contribute", Proceedings of the Institute of Concrete Technology Annual Technical Symposium, Institute of Concrete Technology Camberley, UK (2003).

15. Wang, L., Tian, P., and Yao, Y. "Application of ground granulated blast furnace slag in high-performance concrete in China", Proceedings of International Conference on Sustainability and Concrete Technology, Beijing, China (2004).

16. Thomas, M.D.A., Optimizing Fly Ash Content for Sustainability, Durability, and Constructability, University of New Brunswick, Department of Civil Engineering, Canada (2010).

17. Davis, R.E., Carlson, R.W., Kelly, J.W., and Davis, H.E. "Properties of cements and concretes containing fly ash", Journal of the American Concrete Institute, 33, pp. 577-611 (1937).

18. British standard institute BS EN 450-1:2012, Fly Ash for Concrete, Definition, Specification and Conformity Criteria, London: British Standard Institute (2012).

19. ACI Committee 226 "Use of fly ash in concrete", $A C I$ Mater J., 84(5), pp. 381-409 (1987).

20. Dhir, R.K. "Pulverised-fuel ash", Concrete Technology and Design, Cement Replacement Materials, Surrey University Press, London, 33, Ch. 7, pp. 197-255 (1986).

21. Kayali, O. and Ahmed, M.S. "Assessment of high volume replacement fly ash concrete - Concept of performance index", Construction and Building Materials, 39, pp. 71-76, Elsevier (2013).

22. Neville, A.M., Properties of Concrete, Longman Group Limited, 4th Edn., London, England (1995).

23. Malhotra, V.M. and Mehta, P.K., High-Performance, High-Volume Fly Ash Concrete. Supplementary Cementing Materials for Sustainable Development, Inc., Ottawa, Canada, 124 pages (2005).

24. Yang, E.H., Yang, Y., Li, V.C. "Use of high volumes of fly ash to improve ECC mechanical properties and material greenness", ACI Materials Journal, 104(6), pp. 620-628 (2007).

25. Lepech, M.D., Li, V.C., Robertson, R.E., and Keoleian, G.A. "Design of green engineered cementitious composites for improved sustainability", ACI Materials Journal, 105(6), pp. 568-575 (2008).

26. Qureshi, M.N. and Somnath, G. "Effect of curing conditions on the compressive strength and microstructure of alkali-activated GGBS paste", International Journal of Engineering Science Invention, 2(2), pp. 24-31 (2013).

27. Islam, M.M., Islam, M.S., Mondal, B.P., and Islam, M.R. "Strength behavior of concrete using slag with cement in sea water environment", Journal of Civil Engineering (IEB), 38(2), pp. 129-140 (2010). 
28. Barnett, S.J., Soutsos, M.N., Millard, S.G., and Bungey, J.H. "Strength development of mortars containing ground granulated blast-furnace slag", Effect of curing temperature and determination of apparent activation energies", Cement and Concrete Research, 36, pp. 434-440 (2010).

29. Safan, M. and Kohoutková, A. "Influence of different drying conditions on high strength concrete compressive strength", Acta Polytechnica, 41(3), pp. 24-28 (2001).

30. Hongen, Z., Ling, T., Xiaoshuang, S., and Wang, Q. "Influence of curing condition on compressive strength of low-calcium fly ash-based geopolymer concrete", Journal of Residuals Science \& Technology, 14(1), p. 1544 (2017).

31. Ki-Bong Park1 and Takafumi Noguchi "Effects of mixing and curing temperature on the strength development and pore structure of fly ash blended Mass Concrete", Advances in Materials Science and Engineering, 27, 11 pages (2017).

32. British Standard Institute BS EN 934-2:2009+A1: 2012, Admixtures for Concrete, Mortar and Grout. Concrete Admixtures. Definitions, Requirements, Conformity, Marking and Labelling (2012).

33. British Standard Institute BS EN 12620-1: 2009, Aggregates for Concrete, London, British Standard Institute (2009).

34. British Standards Institution BS EN 12390-3: 2009, Testing Hardened Concrete, Part 3: Compressive Strength of Test Specimens, London: British Standards Institute (2009).

\section{Biographies}

Shahab Samad is currently an Assistant Professor at Civil Engineering Department, City University of Science and IT, Pakistan. He received his BS from UET Peshawar Pakistan and MS from City University London, UK. He obtained his PhD from Kingston
University London. He worked as a Structural Engineer with GD Partner, UK, and as Lecturer at Kingston University, UK. His research areas include, use of supplementary cementitious material in concrete, binary cement and design of steel structures.

Attaullah Shah is a Professor of Civil Engineering at City University of Science and IT Pakistan. He received his BS and MS from UET Peshawar, Pakistan and PhD from UET Taxila, Pakistan. He is also the corresponding author. His research areas include shear properties of high strength concrete, retrofitting of damaged RC structures, and sustainable built environment.

Mukesh C Limbachiya is a Professor of Civil Engineering and the Head of Natural and Built Environment, Faculty of Science, Engineering and Computing at Kingston University, UK. He received his BS Civil Engineering from Jeevan Sadhana, India, MS from University of Baroda, Manchester, and PhD from Hallam University, UK. Professor Limbachiya has been a member of numerous prestigious bodies, namely Fellow of Institution of Civil Engineers, UK, Chartered Engineer, UK, FICE and many more. His areas of interest include the use of blended cement in RC, reuse of waste material, and retrofitting of damaged structures.

Satish B Desai is a Professor at Kingston University, London, PhD Civil Engineering, Chartered Engineer (CEng), Fellow of the Institution of Civil Engineers and the Institute of Materials, Minerals \& Mining, with a strong demonstrable experience of strategic leadership and management in a multidisciplinary higher education sector. He has an academic career with an extensive experience of teaching and curriculum development. 